\title{
Dopamine synergizes with caffeine to increase the heart rate
}

\section{of Daphnia [version 1; peer review: 1 approved, 2 approved}

\section{with reservations]}

\author{
Aman Kundu1, Gyanesh Singh (iD)2 \\ ${ }^{1}$ Fs Convent School, Jind, Hariyana, 126113, India \\ ${ }^{2}$ School of Bioengineering and Biosciences, Lovely Professional University, Phagwara, Punjab, 144411, India
}

V1 First published: 01 Mar 2018, 7:254

https://doi.org/10.12688/f1000research.12180.1

Latest published: 01 Mar 2018, 7:254

https://doi.org/10.12688/f1000research.12180.1

\section{Abstract}

Dopamine is a key neurotransmitter, and is widely used as a central nervous system (CNS) agent. Dopamine plays an important role in humans, including a major role in reward and motivation behaviour. Several addictive drugs are well known to increase neuronal dopamine activity. We selected Daphnia, an important model organism, to investigate the effect(s) of selected CNS agents on heart rate. Dopamine's effects on Daphnia's heart has not been previously reported. Caffeine is a well-known and widely consumed stimulant. Ethanol is well known for its effects on both neurological and physiological processes in mammals. We tested the effect of dopamine on the heart rate of Daphnia, and compared its effect with caffeine and ethanol alone and in combination. Both caffeine and dopamine were found to instantly increase the heart rate of Daphnia in a dose-dependent manner. Interestingly, caffeine synergized with dopamine to increase Daphnia's heart rate. As ethanol decreased the heart rate of Daphnia and dopamine increased the heart rate of Daphnia, we wanted to test the effect of these molecules in combination. Indeed, Dopamine was able to restore the ethanolinduced decrease in the heart rate of Daphnia. Effects of these CNS agents on Daphnia can possibly be correlated with similar effects in the case of mammals.

\section{Keywords}

Dopamine, heart, neurotransmitter, cardiac, central nervous system

\section{Open Peer Review \\ Approval Status ? ? \\ 12 \\ 23 \\ version 1

$? \quad ?$ \\ 01 Mar 2018

$?$
view \\ view \\ 1. Rafael Antonio Vargas (ID), Pontificia \\ Universidad Javeriana, Bogotá, Colombia \\ 2. Mrinal K. Poddar, University of Calcutta, Kolkata, India \\ 3. Cecilia Scorza, Clemente Estable Institute of Biological Research (IIBCE), Montevideo, Uruguay}

Any reports and responses or comments on the article can be found at the end of the article. 
Corresponding author: Gyanesh Singh (appliedbiotechnologist@gmail.com)

Author roles: Kundu A: Methodology, Validation, Writing - Original Draft Preparation; Singh G: Supervision, Validation, Writing - Review \& Editing

Competing interests: No competing interests were disclosed.

Grant information: The author(s) declared that no grants were involved in supporting this work.

Copyright: $\odot 2018$ Kundu A and Singh G. This is an open access article distributed under the terms of the Creative Commons Attribution License, which permits unrestricted use, distribution, and reproduction in any medium, provided the original work is properly cited. Data associated with the article are available under the terms of the Creative Commons Zero "No rights reserved" data waiver (CC0 1.0 Public domain dedication).

How to cite this article: Kundu A and Singh G. Dopamine synergizes with caffeine to increase the heart rate of Daphnia [version 1; peer review: 1 approved, 2 approved with reservations] F1000Research 2018, 7:254 https://doi.org/10.12688/f1000research.12180.1

First published: 01 Mar 2018, 7:254 https://doi.org/10.12688/f1000research.12180.1 


\section{Introduction}

Neurotransmitters are the key mediators of communication between nerve cells. Because of their effect on brain and spinal cord, central nervous system (CNS) agents can be used to control or treat variety of medical conditions ${ }^{1}$. Stimulation of the hypothalamus can lead to cardiovascular disturbances, indicating a direct connection between the heart and the $\mathrm{CNS}^{2,3}$. Different types of rewards are known to increase the level of dopamine in the brain ${ }^{4}$. Daphnia are small crustaceans commonly known as "water fleas", and are found in water bodies . Daphnia is an ideal organism for research, as it has short life span, and can easily be cultured $^{6}$. These organisms can feed on algae, yeast and bacteria ${ }^{5}$. More importantly, Daphnia are transparent, thus allowing clear visualization of different organs, including the heart ${ }^{7}$. The organs are protected by a thin membrane that allows the penetration of different compounds; therefore assisting with heart rate monitoring in real time ${ }^{5}$. Using a microscope that has computer-aided real-time imaging capabilities, the effect of various compounds can be observed on Daphnia's heart in real time. Daphnia's life span is 40-50 days, which varies in different species and also changed with environmental conditions, especially temperature. Male and female Daphnia can easily be differentiated, as female Daphnia have brood pouch that holds eggs. These eggs develop into embryos, leading to the production of juveniles that attain sexual maturity within ten days.

Dopamine is important for normal cardiopulmonary response to exercise and is necessary for optimal high-intensity exercise performance. Blocking dopamine receptors appears to be detrimental to exercise performance ${ }^{8}$. Caffeine, by antagonizing adenosine A2A receptors, is known to augment dopamine signalling in the brain $^{9,10}$. Even at routine doses, caffeine can enhance dopamine receptor accessibility in the mammalian $\mathrm{CNS}^{10}$. Caffeine has also been reported to normalize the heart rate of Daphnia, which is decreased by atropine and atenolol ${ }^{11}$. Ethanol is known to cause progressive weakness, difficulty in walking, and lowered heart rate $^{12}$. Ethanol also inhibits calcium dependent neurotransmitter release, and, excitatory and inhibitory postsynaptic potentials in cultured spinal cord neurons ${ }^{13}$.

The aim of the present study was to investigate the effect of Dopamine on Daphnia's heart rate, alone and in combination of caffeine and ethanol. The rationale behind this research was that both caffeine and ethanol are known to affect nervous system functions $s^{14}$, and dopamine is a major neurotransmitter.

\section{Methods}

\section{Daphnia culture}

Daphnia were isolated from Chitti Vai river of Punjab. For the isolation of Daphnia, 0.5-2.0 litres of river water was collected and transported to laboratory. Adult Daphnia were manually identified as per the standard identification features ${ }^{15}$, and filtered out using muslin cloth. These adults were cultured in $300 \mathrm{ml}$ glass jars containing river water that was filtered with muslin cloth. Daphnia culture was supplemented with $0.5 \%$ yeast culture, added every third day. Yeast culture, in this case, was used as a food for Daphnia. Algae, yeast or bacteria are preferred food for Daphnia. Although, many workers use river water for Daphnia culture presuming that it would have better mineral composition, in our case, we were also able to culture Daphnia in aged tap water in the similar manner. Cultures were routinely monitored to ensure production of healthy Daphnia.

\section{Counting of Daphnia's heart rate}

To investigate the effect of certain agents on the heart rate of Daphnia, real-time monitoring of changes in the heart rate of Daphnia is required. We used a microscope equipped with computer-aided real-time imaging capability (Magnus Live usb camera viewer, version 2.0, Magnus Analytics, New Delhi110044, India), and for each reading heart rate was initially counted without any treatment (control). Subsequently, changes in the heart rate was monitored after the addition of selected agents. Each Daphnia was placed on the glass slide with 100 ul of water. The slide was observed in real time under the microscope at $40 \mathrm{x}$ or $100 \mathrm{x}$ magnification, and heart rate was counted. To avoid the effect of temperature or other environmental factors, counting was done after five seconds of starting the microscope. Subsequently, the microscope was switched off for five seconds, cardiovascular agents were added (see Table 1), and heart rate was counted again.

\section{Statistical analysis}

A paired t test analysis was done to compare changes in heart rates upon treatment with different agents. Statistical analyses were performed using GraphPad Prism version 6.00 for Windows (GraphPad Software, San Diego, CA, USA). P<0.05 was considered significant.

\section{Results and discussion}

Dopamine, like caffeine, increases the heart rate of Daphnia in a dose-dependent manner

Dopamine's effects on Daphnia's heart has not been reported previously. We hereby report that dopamine instantly increases the heart rate of Daphnia in a dose-dependent manner, and a significant increase $(25.7 \%)$ in the heart rate was observed, even at a low dose of $0.8 \mathrm{mg} / \mathrm{ml}$ (Figure 1). Caffeine showed a similar

Table 1. Central nervous system agents used.

\begin{tabular}{|l|l|}
\hline Name (source) & Concentrations \\
\hline $\begin{array}{l}\text { Caffeine (Loba Chemie Pvt Ltd, } \\
\text { Mumbai, India) }\end{array}$ & 0.08 to $0.32 \mathrm{mg} / \mathrm{ml}$ \\
$\begin{array}{l}\text { Dopamine (Amrit Pharmaceuticals, } \\
\text { Aurangabad, India) }\end{array}$ & 0.4 to $3.2 \mathrm{mg} / \mathrm{ml}$ \\
\hline $\begin{array}{l}\text { Ethanol (Himedia Laboratories, } \\
\text { Mumbai, India) }\end{array}$ & $2-8 \%$ \\
\hline
\end{tabular}


effect on Daphnia's heart rate at a 10-times lower concentration than dopamine $(28.5 \%$ increase at $0.08 \mathrm{mg} / \mathrm{ml}$, Figure 2). Dopamine is the precursor of norepinephrine, and has been shown to augment heart activity by affecting beta-adrenergic receptors, in the case of a canine model ${ }^{16}$. Furthermore, dopamine can cause both relaxation and contraction of vascular smooth muscle. Dopamine is also known to augment heart activity, pulmonary pressure, and cardiac index in the case of normal and hypertensive individuals ${ }^{17}$.

Dopamine synergizes with caffeine to increase the heart rate of Daphnia

Caffeine, in combination with dopamine, increased Daphnia's heart rate more than when the agents were administered

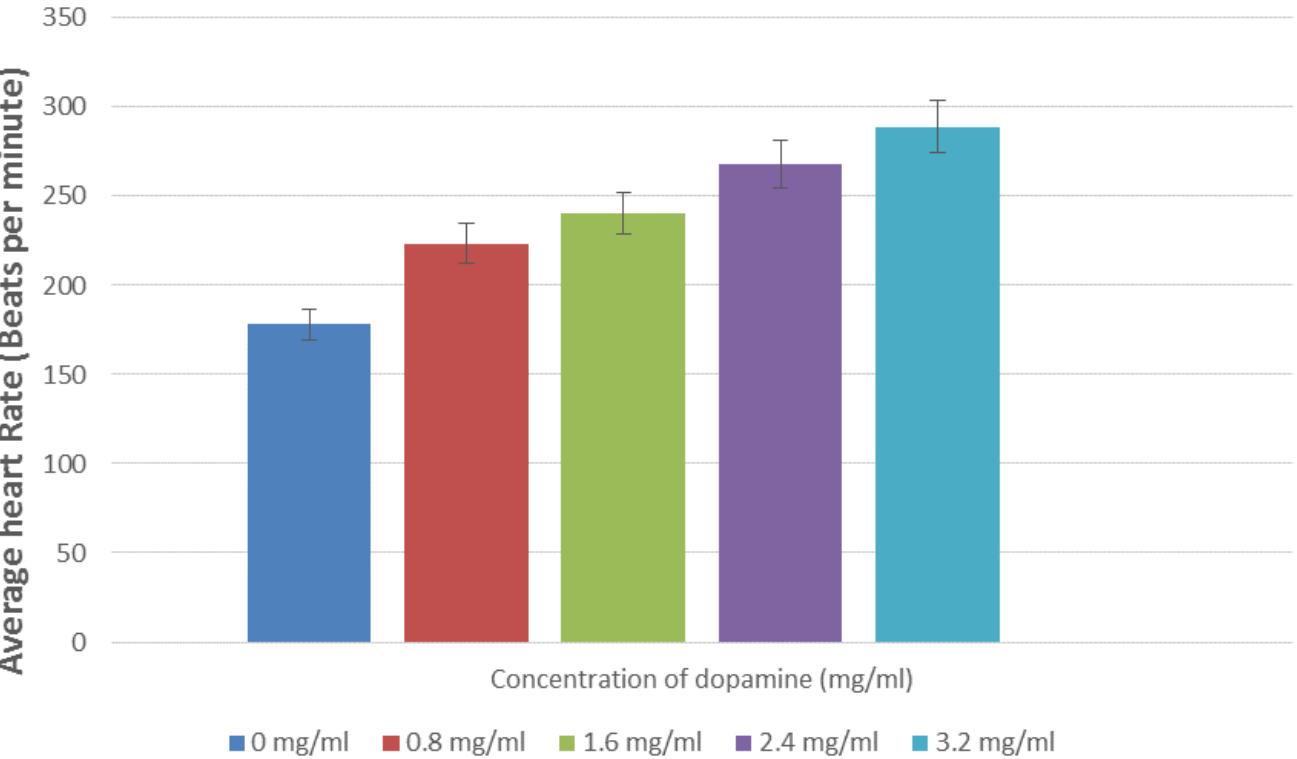

Figure 1. Dopamine increases the heart rate of Daphnia in a dose-dependent manner. This experiment was performed two times, and a paired t test analysis vs control indicated the following P values: 0.0070 (for $0.8 \mathrm{mg} / \mathrm{ml}), 0.0255(1.6 \mathrm{mg} / \mathrm{ml}), 0.0424(2.4 \mathrm{mg} / \mathrm{ml})$, and 0.0344 $(3.2 \mathrm{mg} / \mathrm{ml})$. These values are statistically significant.

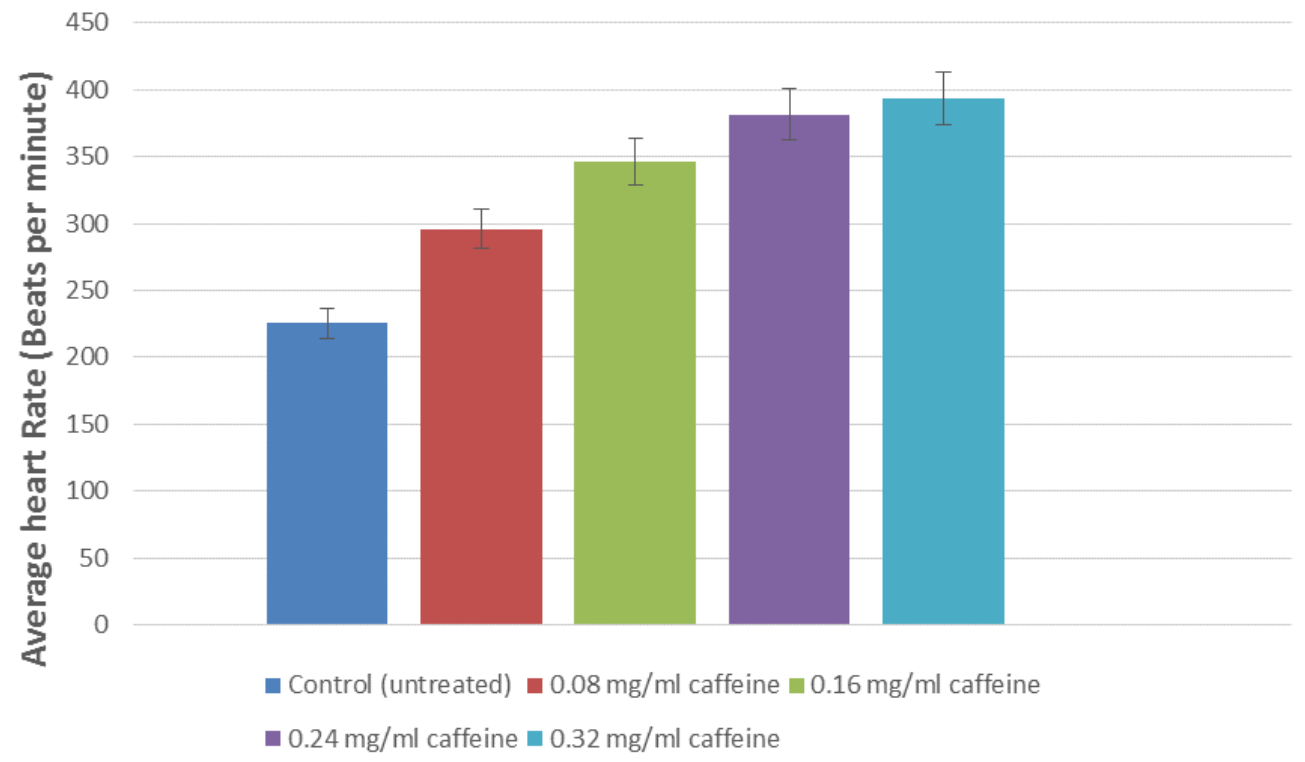

Figure 2. Caffeine increases the heart rate of Daphnia in a dose-dependent manner. This experiment was done two times, and a paired t test analysis vs control revealed the following $P$ values: $0.0406(0.08 \mathrm{mg} / \mathrm{ml}), 0.0263(0.16 \mathrm{mg} / \mathrm{ml}), 0.0367(0.24 \mathrm{mg} / \mathrm{ml})$, and 0.0189 $(0.32 \mathrm{mg} / \mathrm{ml})$. These values are statistically significant. 
alone, which suggests a synergistic activity (Figure 3). Dopamine has also been previously reported to play a role in the responses of Drosophila to cocaine, nicotine or ethanol ${ }^{18}$.

Dopamine overcomes an ethanol-induced decrease of the heart rate of Daphnia

To see the effect on the heart rate of Daphnia, ethanol was used at a concentration ranging from $2-8 \%$, and was found to decrease the heart rate of Daphnia in a dose-dependent manner (Figure 4).
We observed that dopamine was able to rescue the ethanolinduced decrease in the heart rate of Daphnia, even at a concentration of $0.4 \mathrm{mg} / \mathrm{ml}$ (Figure 5).

Dataset 1. Effect of dopamine, caffeine and ethanol on the heart rate of Daphnia

http://dx.doi.org/10.5256/f1000research.12180.d194189

Heart rates (beats per minute) was initially counted without any treatment (controls). Subsequently, changes in the heart rate was monitored after the addition of selected agents.

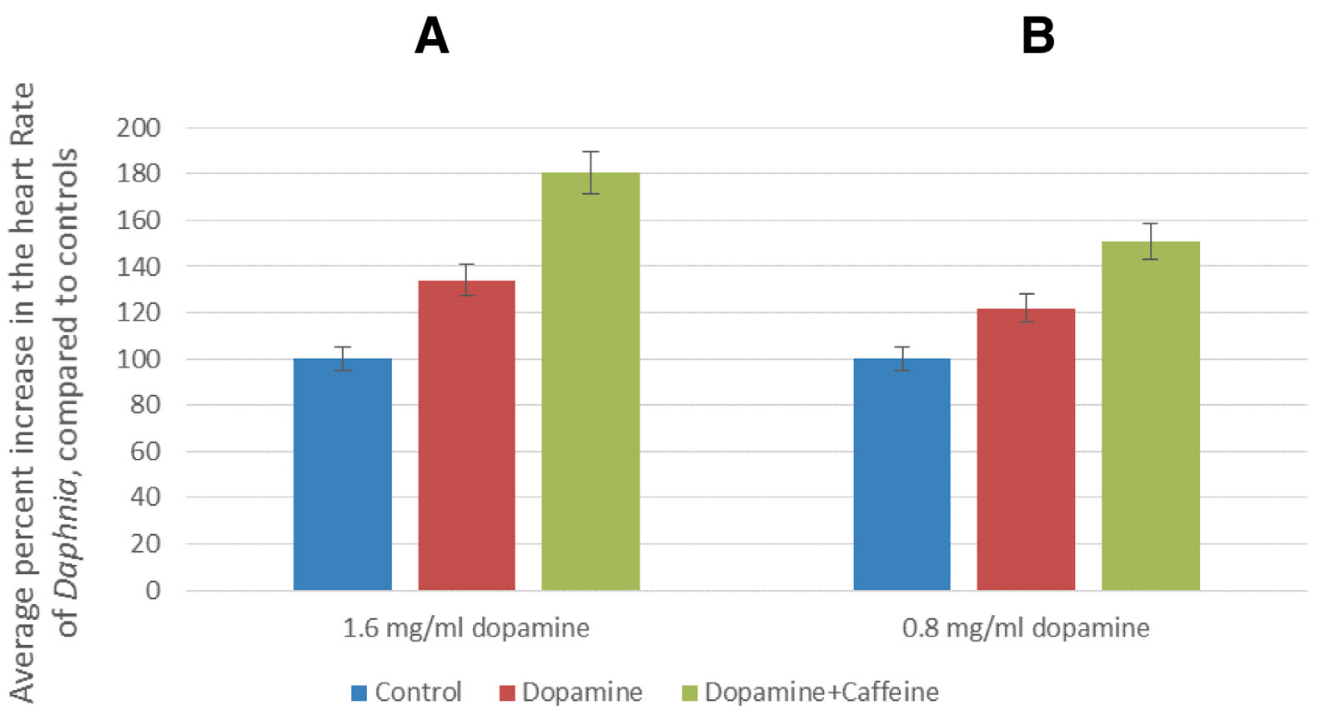

Figure 3. Dopamine synergizes with caffeine to increase the heart rate of Daphnia. Daphnia's heart rate was measured upon treatment with dopamine alone (red) or a combination of dopamine and caffeine (green). The concentration of caffeine (in combination with dopamine) was (A) $40 \mathrm{ug} / \mathrm{ml}$ and (B) $120 \mathrm{ug} / \mathrm{ml}$. This experiment was performed two times, and a paired t test analysis vs control indicated the following $P$ values: 0.0374 (0.8 $\mathrm{mg} / \mathrm{ml}$ dopamine) and $0.0230(1.6 \mathrm{mg} / \mathrm{ml}$ dopamine). These values are statistically significant.

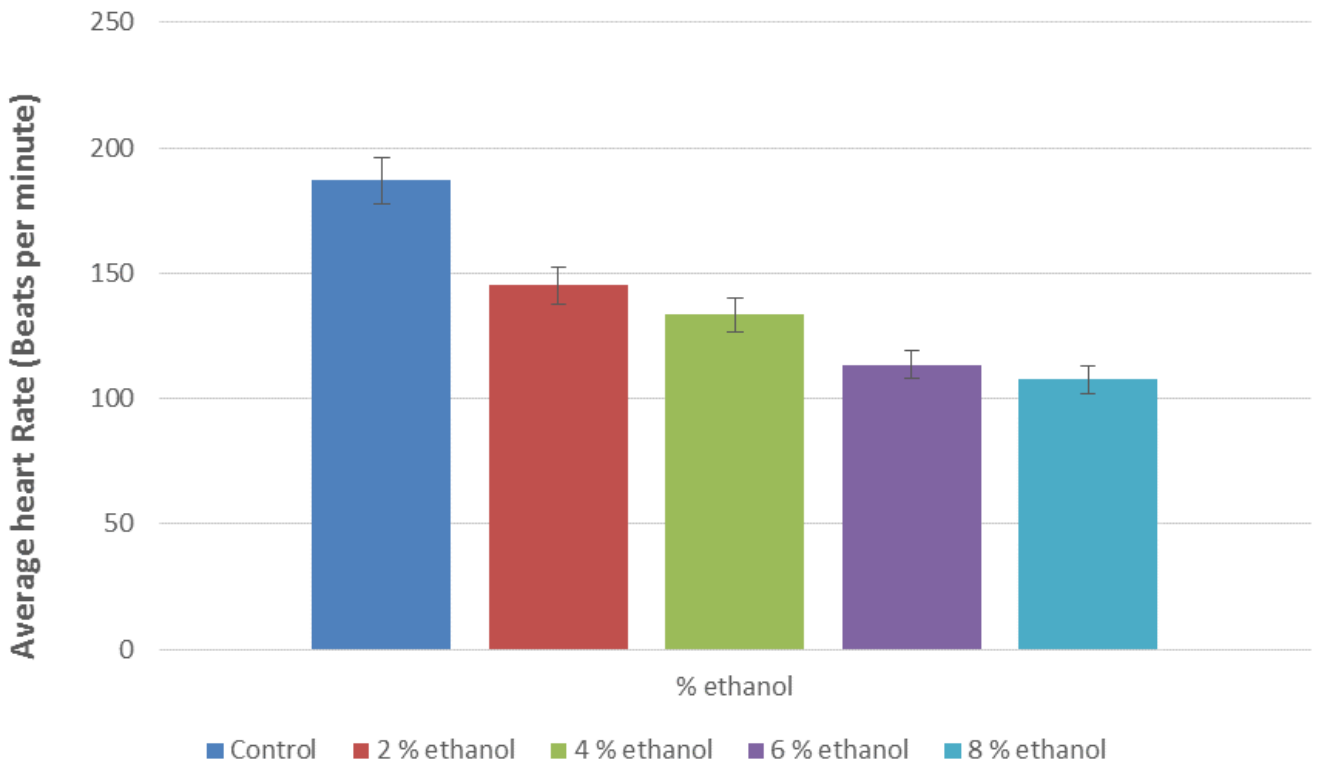

Figure 4. Effect of ethanol on the heart rate of Daphnia. This experiment was done two times, and a paired test analysis vs control indicate the following P values: 0.0152 ( $2 \%$ ethanol), 0.0059 (4\% ethanol), 0.0130 ( $6 \%$ ethanol), and 0.0280 ( $8 \%$ ethanol). These values are statistically significant. 


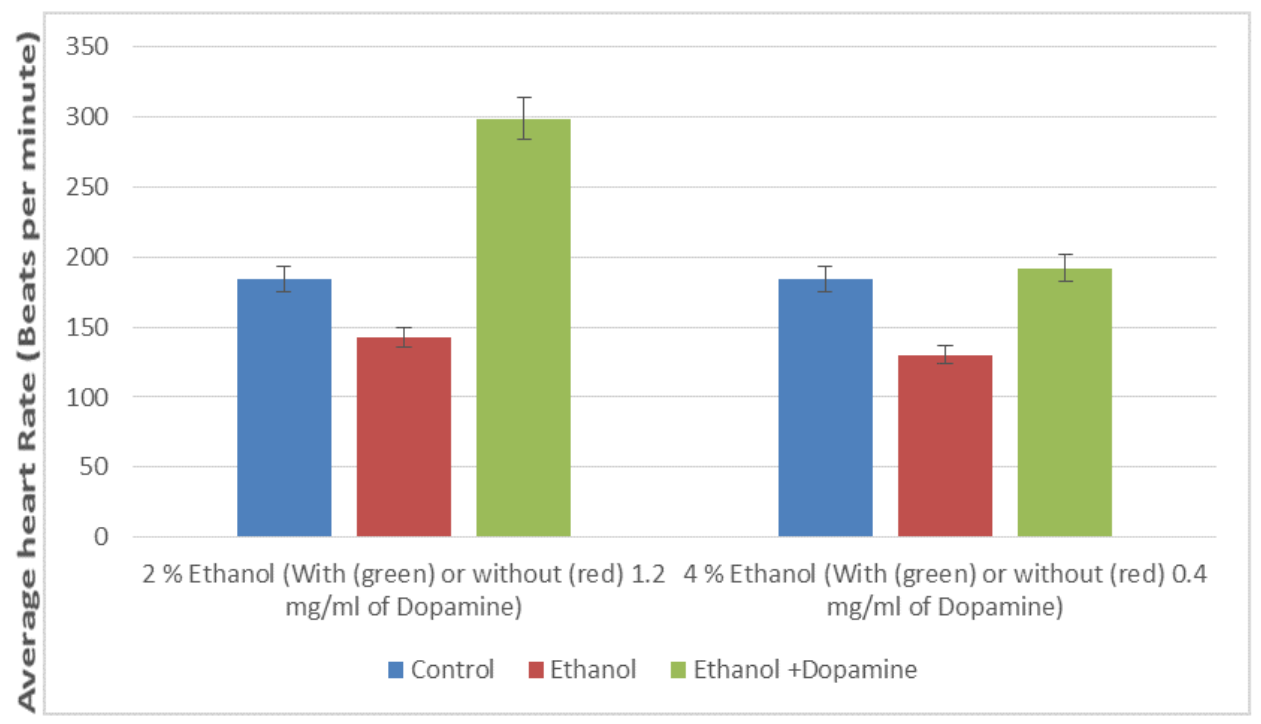

Figure 5. Dopamine overcomes the ethanol-induced decrease on the heart rate of Daphnia. At 2\% ethanol, dopamine-induced increase in the heart rate was $62.5 \%$ compared to control, and $84.8 \%$ compared to ethanol-induced heart rate. At $4 \%$ ethanol, dopamine-induced increase in the heart rate was $4.3 \%$ compared to control, and $33.7 \%$ compared to ethanol-induced heart rate.

\section{Conclusion}

This fundamental investigation can be of enormous importance, as caffeine and ethanol are the most widely consumed psychoactive drugs, and dopamine is a master neurotransmitter that is known to be involved in variety of diseases ${ }^{19,20}$. It is possible that these psychoactive agents can have similar or more drastic effects in humans. It is, therefore, very important to urgently investigate the effect of these psychoactive agents, alone or in combination, in humans. Such studies can provide crucial information that can be used in a variety of clinical settings. For example, cases of alcohol or caffeine intoxication can be managed by dopamine therapy, treatment(s) of cardiac disorders may be different for alcoholics or coffeeholics, and patients undergoing dopamine therapy need to be regularly monitored for cardiothoracic status, and alcohol/caffeine consumption.

\section{Data availability}

Dataset 1: Effect of dopamine, caffeine and ethanol on the heart rate of Daphnia. Heart rates (beats per minute) was initially counted without any treatment (controls). Subsequently, changes in the heart rate was monitored after the addition of selected agents. DOI, 10.5256/f1000research.12180.d194189²1

\section{Competing interests}

No competing interests were disclosed.

\section{Grant information}

The author(s) declared that no grants were involved in supporting this work.

\section{Acknowledgments}

The authors are thankful to Devika Chanu Khaidem of Zoological Survey of India (Kolkata, India) for her help while doing experiments.
1. Soddu E, Rassu G, Giunchedi $P$, et al:: From naturally-occurring neurotoxic agents to CNS shuttles for drug delivery. Eur J Pharm Sci. 2015; 74: 63-76. PubMed Abstract | Publisher Full Text

2. Arnsten AF, Wang M, Paspalas CD: Dopamine's Actions in Primate Prefrontal Cortex: Challenges for Treating Cognitive Disorders. Pharmacol Rev. 2015; 67(3): 681-96.

PubMed Abstract | Publisher Full Text | Free Full Text

3. Osteraas ND, Lee VH: Neurocardiology. Handb Clin Neurol. 2017; 140: 49-65. PubMed Abstract | Publisher Full Text

4. Peinado $\mathrm{AB}$, Rojo JJ, Calderón FJ, et al:: Responses to increasing exercise upon reaching the anaerobic threshold, and their control by the central nervous system. BMC Sports Sci Med Rehabil. 2014; 6: 17.

PubMed Abstract | Publisher Full Text | Free Full Text

5. Stollewerk A: The water flea Daphnia -- a 'new' model system for ecology and evolution? J Biol. 2010; 9(2): 21

PubMed Abstract | Publisher Full Text | Free Full Text

6. Shaw JR, Pfrender ME, Ead BD, et al.: Daphnia as an emerging model for toxicological genomics. Adv Exp Biol. 2008; 2: 165-219. Publisher Full Text

7. Harris KD, Bartlett NJ, Lloyd VK: Daphnia as an emerging epigenetic model 
organism. Genet Res Int. 2012; 2012: 147892.

PubMed Abstract | Publisher Full Text | Free Full Text

8. Tedjasaputra V, Bryan TL, van Diepen S, et al:: Dopamine receptor blockade improves pulmonary gas exchange but decreases exercise performance in healthy humans. J Physiol. 2015; 593(14): 3147-57.

PubMed Abstract | Publisher Full Text | Free Full Text

9. Zeitzer JM: Control of sleep and wakefulness in health and disease. Prog Mol Biol Transl Sci. 2013; 119: 137-54.

PubMed Abstract | Publisher Full Text

10. Volkow ND, Wang GJ, Logan J, et al:: Caffeine increases striatal dopamine $D_{2} / D_{3}$ receptor availability in the human brain. Transl Psychiatry. 2015; 5(4): e549. PubMed Abstract | Publisher Full Text | Free Full Text

11. Podosinovikova NP, Beliaev VA, Dolgo-Saburov VB: [Studying intermediatory regulation of heart rhythm using Daphnia magna as the alternative test object]. Eksp Klin Farmakol. 2009; 72(6): 49-51.

PubMed Abstract

12. Horn-Hofmann $C$, Büscher $P$, Lautenbacher $S$, et al:: The effect of nonrecurring alcohol administration on pain perception in humans: a systematic review. J Pain Res. 2015; 8: 175-87.

PubMed Abstract | Publisher Full Text | Free Full Text

13. Noori HR, Spanagel R, Hansson AC: Neurocircuitry for modeling drug effects. Addict Biol. 2012; 17(5): 827-64. PubMed Abstract | Publisher Full Text

14. Ferré S, O'Brien MC: Alcohol and Caffeine: The Perfect Storm. J Caffeine Res.
2011; 1(3): 153-162.

PubMed Abstract | Publisher Full Text | Free Full Text

15. Ebert D: Ecology, Epidemiology, and Evolution of Parasitism in Daphnia Zoologisches Institut der Universität Basel, National Center for Biotechnology Information (US). 2005. ISBN-10: 1-932811-06-0 Reference Source

16. Goldberg LI: Dopamine--clinical uses of an endogenous catecholamine. N Engl J Med. 1974; 291(14): 707-10.

PubMed Abstract | Publisher Full Text

17. Holloway EL, Polumbo RA, Harrison DC: Acute circulatory effects of dopamine in patients with pulmonary hypertension. Br Heart J. 1975; 37(5): 482-5. PubMed Abstract | Publisher Full Text | Free Full Text

18. Bainton RJ, Tsai LT, Singh CM, et al.: Dopamine modulates acute responses to cocaine, nicotine and ethanol in Drosophila. Curr Biol. 2000; 10(4): 187-94. PubMled Abstract | Publisher Full Text

19. Blum K, Thanos PK, Gold MS: Dopamine and glucose, obesity, and reward deficiency syndrome. Front Psychol. 2014; 5: 919. PubMed Abstract | Publisher Full Text | Free Full Text

20. Rodan LH, Gibson KM, Pearl PL: Clinical Use of CSF Neurotransmitters. Pediatr Neurol. 2015; 53(4): 277-86.

PubMed Abstract | Publisher Full Text

21. Kundu A, Singh G: Dataset 1 in: Dopamine synergizes with caffeine to increase the heart rate of Daphnia. F1000Research. 2018.

Data Source 


\section{Open Peer Review}

\section{Current Peer Review Status: $\checkmark$ ? ?}

\section{Version 1}

Reviewer Report 27 June 2018

https://doi.org/10.5256/f1000research.13184.r35079

(C) 2018 Scorza C. This is an open access peer review report distributed under the terms of the Creative Commons Attribution License, which permits unrestricted use, distribution, and reproduction in any medium, provided the original work is properly cited.

\section{Cecilia Scorza}

Department of Experimental Neuropharmacology, Clemente Estable Institute of Biological Research (IIBCE), Montevideo, Uruguay

The study "Dopamine synergizes with caffeine to increase the heart rate of Daphnia" done by Aman Kundu and Gyanesh Singh, investigates the effect of dopamine, caffeine and alcohol on Daphnia's heart rate. Also the combination of caffeine and ethanol was tested. The rationale of the paper was to use the Daphnia's heart rate to test treatment(s) of cardiac disorders in high consumers of coffee or alcohol. The importance and objectives of the study are well explained and methods are well described, although some aspects of this manuscript should be really improved and corrected.

The statistical Analysis applied is not correct; consequently I have some doubts if the results would be the same applying a correct statistical analysis. Authors used t-paired test to evaluate a dosedependence curve in which more than two concentrations are compared. I suggest to authors apply One-Way ANOVA followed by a post hoc test (for example, Newman-Keuls). Additionally, authors indicated that the experiments were done two times. I understand that this means that a duplicate of each experiment were performed, is it correct?. If this is the case, a mean \pm SD should be used to compare data. Please, correct.

Another important issue is about the synergism. Author concluded that dopamine synergizes with caffeine to increase the heart rate of Daphnia. But, synergism should be declared if a subthreshold concentrations of DA and Caff is used. If not, only a potentiation is achieved.

Please, correct the terminology of synergism or other experiments should be done using the combination of sub-threshold doses of DA and Caff.

It would be very important to add positive controls to test Daphnia's heart rate, for example, noradrenaline or atropine, both are prototypical substances that increase heart rate in vertebrate animals.

In the conclusion: in addition to the purpose of this kind of assay, I wondering if Daphnia's heart rate assay could be more suitable as a biomarker of toxicity instead of serve as a screening test of 
different drugs to alter Daphnia's heart rate?

Competing Interests: No competing interests were disclosed.

I confirm that I have read this submission and believe that I have an appropriate level of expertise to confirm that it is of an acceptable scientific standard, however I have significant reservations, as outlined above.

Reviewer Report 13 April 2018

https://doi.org/10.5256/f1000research.13184.r31349

(C) 2018 Poddar M. This is an open access peer review report distributed under the terms of the Creative Commons Attribution License, which permits unrestricted use, distribution, and reproduction in any medium, provided the original work is properly cited.

Mrinal K. Poddar

Department of Biochemistry, University of Calcutta, Kolkata, India

The original article written by Kundu and Singh focuses on the study of the effects of cardiovascular drugs of the heart rate of Daphnia. In this study the authors have used an interesting heart model of Daphnia.

The article represents the synergistic effect of dopamine and caffeine to increase the heart rate in Daphnia, the tiny water fleas. Though, neither this model can be compare with mammals nor their organ function. The authors have tried to show some effects without mentioning the mechanism of effects. I think they should clarify the followings points:

1. Authors have analyzed the data with a simple t test. Why they didn't they approach with ANOVA test? Moreover, statistical analysis with only two observations is not sufficient. Observations should be made of at least four times for significance test.

2. In Figures, the vertical line given on top of each bar represents what? - SEM or SD?

3. Table 1 shows the lowest concentration of dopamine as $0.4 \mathrm{mg} / \mathrm{ml}$ which is missing in the entire manuscript. Where is the result of $0.4 \mathrm{mg} / \mathrm{ml}$ ?

4. Why did the authors choose $40 \mu \mathrm{g}$ or $120 \mu \mathrm{g} / \mathrm{ml}$ instead of $\mathrm{mg} / \mathrm{ml}$ that they have tested and represented in Figure 1. What is the reason of this sudden switch over? Nothing is clear to me! 5. In Figure 3 Why the authors have used the combination of lower concentration of caffeine $(40 \mu \mathrm{g} / \mathrm{ml})$ with higher concentration of dopamine $(1.6 \mathrm{mg} / \mathrm{ml})$ and higher concentration of caffeine $(120 \mu \mathrm{g} / \mathrm{ml})$ with lower concentration of dopamine $(0.8 \mathrm{mg} / \mathrm{ml})$ ? This needs clarification.

6. Figure 5 have the same queries like Figure 3 and it should be better in both the cases of combinations, keep one constant and vary the other one.

7. The Daphnia model does not directly resemble the mammalian system. The conclusion they have made in the manuscript requires rethinking and should be presented accordingly.

8. In the manuscript the authors didn't mention about the treatment procedure. How have they administered the dopamine, caffeine or alcohol? What is the route of administration of these compounds? Are those administered or given in the culture medium? Depending on the route of administration for this particular model, the author should discuss about the mechanism of action 
of these agents on Daphnia heart rate or cardiovascular system.

Suggestions:

I think for indexing following works are needed to improve the manuscript:

1. Redesign the experiments as I suggested.

2. More observations (at least 4) for each experiment are needed.

3. Proper statistical analysis is essential. Simple t test is not enough as the experiment are in combination of different agents.

\section{References}

1. Kundu A, Singh G: Dopamine synergizes with caffeine to increase the heart rate of Daphnia. F1000Research. 2018; 7. Publisher Full Text

Competing Interests: No competing interests were disclosed.

\section{I confirm that I have read this submission and believe that I have an appropriate level of expertise to confirm that it is of an acceptable scientific standard, however I have significant reservations, as outlined above.}

Reviewer Report 09 March 2018

https://doi.org/10.5256/f1000research.13184.r31347

(C) 2018 Vargas R. This is an open access peer review report distributed under the terms of the Creative Commons Attribution License, which permits unrestricted use, distribution, and reproduction in any medium, provided the original work is properly cited.

\section{Rafael Antonio Vargas}

Departamento de Ciencias Fisiológicas, Facultad de Medicina, Pontificia Universidad Javeriana, Bogotá, Colombia

The original article by Kundu and Singh focuses on the study the effects of cardiovascular drugs on the heart rate of Daphnia. The authors have used an interesting heart model: Daphnia. This model has some advantages in comparison with classical animal models such as rats, mice, dogs, cats, and others. This model could be interesting for researchers from undeveloped countries. The study shows the effect of dopamine, caffeine, and alcohol on Daphnia heart rate (HR), which has been studied in other animal models. In this case, it is shown that dopamine and caffeine increase HR, and alcohol reduces HR. Interestingly, dopamine restores the low HR ethanolinduced. The authors claim that it's probably similar effects of this agents in humans, however, the Daphnia heart does not represent a direct analog of mammalian cardiac function, so the interpretation of the results of the present study in terms of mammals is problematic. I have two comments/questions:

1. It is mentioned in the introduction, that atropine and atenolol decrease $\mathrm{HR}$ and this is not true in humans: Atenolol, a beta blocker reduces HR, but atropine, a cholinolytic agent, increase $H R$, so this statement must be revised. 
2. It could be useful if the authors add the how HR was performed.

In general, after reading this submission, I consider that this is a short and interesting article about a simple model which will be useful for students, young researchers interested in alternatives to study cardiovascular function. After clarifying the comments the paper can be indexed.

\section{References}

1. Das G: Therapeutic review. Cardiac effects of atropine in man: an update.Int J Clin Pharmacol Ther Toxicol. 1989; 27 (10): 473-7 PubMed Abstract

2. Takahashi H, Fukuyama M, Yoneda S, Okabayashi $\mathrm{H}$, et al.: Comparison of nisoldipine and atenolol in the treatment of essential hypertension.Arzneimittelforschung. 1989; 39 (3): 379-82 PubMed Abstract

Competing Interests: No competing interests were disclosed.

Reviewer Expertise: Cardiovascular physiology, neurophysiology, animal models

I confirm that I have read this submission and believe that I have an appropriate level of expertise to confirm that it is of an acceptable scientific standard.

\section{Comments on this article}

\section{Version 1}

Author Response 21 Sep 2018

Gyanesh Singh, Lovely Professional University, Phagwara, India

Many thanks for your valuable suggestions. After looking at the datasets, i believe that dopamine increases heart rate. I also have few unpublished datasets including 2 more for figure 5, where dopamine clearly overcomes the effect of ethanol on the heart rate. These experiments were part of a study, where 18 different molecules were tested for their effect on heart rate, however, only caffeine, dopamine and ethanol showed drastic changes.

Penalva, et al's report (Hydrobiologia, 2007) that you mentioned probably did not see the effect of dopamine on the heart rate of daphnia because they treated Daphnia for 1 hour, as they have mentionioned in the beginning of their result that "This indicates that dopamine does not significantly alter Daphnia heart rate at concentrations below $10 \mathrm{mM}$ after $1 \mathrm{~h}$ ".

I will write more after looking at this in more detail.

Competing Interests: none 


\section{Matthew Beckman, Augsburg University, USA}

This paper is interesting to me but there are some major issues with the manuscript. First, the assertion that the effect of dopamine on heart-rate has never been studied in Daphnia is not true. Here is a citation for a published report: Studying Daphnia feeding behavior as a black box: a novel electrochemical approach Hydrobiologia, 2007, Volume 594, Number 1, Page 153 D. C. PeñalvaArana, P. A. Moore, B. A. Feinberg. In this study Penalva, et al. show a dose response for dopamine on heart-rate in Daphnia. Also, it would be more convincing with the following: 1) report the total number of animals studied in each condition. We assume that more than two animals were studied per condition because error bars are shown. 2) report whether the error bars are SD or SEM. 3) Perform the correct statistical test (1-way ANOVAs). 3) provide some assurance that the effects are really due to the drugs added. For instance, could you demonstrate "wash-out" or "recovery" from the drug effect? How were drug solutions prepared? If the dopamine was in tap water how did you insure it wasn't oxidized? If fresh stocks of dopamine were made and used soon it may not have been an issue.4) address what you mean by a pharmacological effect occuring "instantly". Most biological phenomena can best be described as occuring over time and having a "time-constant" even if it is rapid with a very small time-constant. 5) How does dopamine instantly get into the Daphnia heart given that the heart isn't exposed to the media--it is inside the carapace? It would take time for the drug to penetrate the animal and affect heart-rate. 6) a discussion of ethanol effects at the high concentrations you are using. We have shown that much lower concentrations of ethanol kill Daphnia in a rather short period of time. See: Pharmacol Biochem Behav. 2015 Oct;137:101-9. doi: 10.1016/j.pbb.2015.08.010. Epub 2015 Aug 19. Exposure to D2-like dopamine receptor agonists inhibits swimming in Daphnia magna. Barrozo ER ${ }^{1}$, Fowler DA ${ }^{2}$, Beckman ML ${ }^{3}$. At $8 \%$ are Daphnia simply dying or is the ethanol affecting their physiology. Again, a washout experiment would be instructive in this case.

Competing Interests: Daphnia biologist.

The benefits of publishing with F1000Research:

- Your article is published within days, with no editorial bias

- You can publish traditional articles, null/negative results, case reports, data notes and more

- The peer review process is transparent and collaborative

- Your article is indexed in PubMed after passing peer review

- Dedicated customer support at every stage

For pre-submission enquiries, contact research@f1000.com 